\title{
Deskripsi Resiliensi pada Pria Tunadaksa Non Bawaan yang Bekerja \\ ${ }^{1}$ Marissa Hardy Kusuma Dewi, ${ }^{2}$ Suwarti \\ Fakultas Psikologi, Universitas Muhammadiyah Purwokerto Email: marissahardy512@gmail.com ${ }^{1}$, suwartidarman@gmail.com²
}

\begin{abstract}
Abstrak
Penelitian ini bertujuan untuk mengkaji resiliensi pada pria tunadaksa non bawaan yang bekerja sebagai karyawan. Penelitian ini menggunakan pendekatan studi kasus dengan teknik Purposive Sampling. Metode pengumpulan data menggunakan wawancara. Metode analisis data menggunakan model interaktif Miles dan Huberman. Hasil penelitian menunjukan bahwa resiliensi pada pria tunadaksa non bawaan yang bekerja sebagai karyawan masuk dalam kategori baik. Ditemukan bahwa dalam menghadapi permasalahan seperti menerima kritikan mengenai kondisi fisik dan menanggapinya dengan diam dan tersenyum. Membuat informan belajar mengontrol emosi (emotion regulation). Dapat mengendalikan keinginan, dorongan serta tekanan yang muncul dari dalam diri (impuls control). Memiliki rencana masa depan dan berusaha mewujudkan nya (optimis). Menyadari penyebab permasalahan yang dihadapi (causal analysis) seperti merasakan kesulitan pada tingkat kecepatan dalam mengetik. Memiliki hubungan yang baik dengan rekan kerja maupun lingkungan sekitar rumah, mengerti permasalahan yang dihadapi orang lain (emphaty). Mampu melakukan berbagai usaha untuk dapat memecahkan sebuah permasalahan (self-eficacy). Memiliki kemampuan untuk meningkatkan aspek positif kehidupan dan menghadapi tantangan baru (reaching out).
\end{abstract}

Kata kunci : Bekerja, Pria tunadaksa non bawaan, Resiliensi

\section{Pendahuluan}

Pada dasarnya manusia terlahir dengan memiliki anggota tubuh yang lengkap. Perubahan fisik yang disebabkan karena kecelakan membuat penderita sangat terguncang jiwanya terutama ketika melihat dan mendengar kritikan negatif dari orang sekitar. Musibah tentu bukan suatu hal yang diharapkan oleh setiap orang, karena hal itu dapat memberikan akibat buruk bagi penderita. Terlebih apabila sampai menjadikan seseorang mengalami kecacatan seumur hidup baik dibagian tangan, kaki, maupun bagian tubuh lainya (Pratiwi, 2014).

Data penyandang tunadaksa yang diperoleh dari Dinas Sosial Kabupaten Banyumas pada tahun 2017, terdapat penyandang disabilitas fisik atau tunadaksa 
sebanyak 252 jiwa. Diantaranya 156 penyandang disabilitas fisik atau tunadaksa dengan jenis kelamin laki-laki, dan 96 penyandang disabilitas fisik atau tunadaksa dengan jenis kelamin perempuan.

Greenspan (dalam Anggraeni, 2008) penyandang tunadaksa sangat peduli pada body image, penerimaan dari teman-temannya, kebebasan dari orang tua, penerimaan diri sendiri dan pencapaian prestasi. Akibatnya penyandang tunadaksa sangat mudah marah kepada orang tua, teman-teman dan kepada dirinya sendiri. Karena keadaannya terserang depresi, melakukan tindakan kekerasan, dan bertindak sewenang-wenang akibat perasaan yang dimilikinya.

Tunadaksa dengan kecacatan akibat kecelakaan atau sakit merupakan suatu hal yang sulit diterima oleh individu yang mengalaminya sehingga tidak mengherankan jika penyandangnya memperlihatkan gejolak emosi terhadap kecacatan yang dialaminya dan cenderung tidak dapat menerima keadaan dirinya. Keadaan tubuh individu yang mengalami kecacatan dapat mengakibatkan perasaan rendah diri, frustasi, menarik diri dari lingkunganya, merasa diri tidak berguna, dan sebagainya yang pada giliranya dapat mempengaruhi sejauh mana individu mencapai kebahagiaan dalam hidupnya (Anggraeni, 2008).

Namun faktanya terdapat sejumlah penyandang tunadaksa yang mampu bangkit dari kondisi stress, kemampuan tersebut dinamakan resiliensi (Herman, 2015). Tugade \& Fredrickson (2004) berpendapat bahwa terdapat individu yang mampu bertahan dan pulih dari situasi negatif secara efektif sedangkan ada individu lain yang gagal. Individu tidak berhasil keluar dari situasi yang tidak menguntungkan, kemampuan untuk melanjutkan hidup setelah ditimpa kemalangan atau setelah mengalami tekanan yang berat dikenal dengan istilah resiliensi.

Berdasarkan hal tersebut, tulisan ini dimaksudkan untuk memberikan deskripsi resiliensi pada pria tunadaksa non bawaan yang bekerja ditinjau dari aspek resiliensi. Dari latar belakang dan perumusan masalah yang ada, maka tujuan penelitian ini adalah untuk mengetahui bagaimana resiliensi pada pria tunadaksa 
non bawaan yang bekerja. Manfaat dari penelitian untuk peneliti selanjutnya diharapkan mampu meneliti resiliensi tunadaksa menambahkan faktor resiliensi di dalam penelitian.

\section{Metode}

Penelitian ini menggunakan pendekatan studi kasus. Pemilihan informan menggunakan teknik Purposive Sampling yaitu teknik penentuan sampel dengan pertimbangan tertentu. Jumlah informan dalam penelitian ini berjumlah 3 orang dengan karakteristik informan yaitu yang mengalami tunadaksa non bawaan dan bekerja. Metode yang digunakan dalam pengumpulan data penelitian ini adalah dengan melakukan wawancara tidak terstruktur berdasarkan aspek resiliensi.

\section{Hasil}

Menurut Kaplan (dalam Wiwin, 2018) resiliensi adalah kapasitas untuk mempertahankan kemampuan, untuk berfungsi secara kompeten dalam menghadapi berbagai stressor kehidupan. Menurut Luthar et al., (dalam Dipayanti 2012) resiliensi adalah kemampuan untuk menunjukan adaptasi positif terhadap situasi yang tidak menguntungkan dan pengalaman hidup yang menentang.

Peneliti melakukan wawancara terhadap 3 orang informan berinisial ER, AS dan KA. Berdasarkan hasil wawancara dengan ER berdasarkan aspek relisiensi emotion regulation adalah :

"Kalo sependengaran saya ga pernah".

"Pernah, ya paling kaya gini, bapak yang patah itu kakinya ya saya maklumi aja".

Informan mendapatkan kritikan dari orang yang baru dikenal nya, sementara informan tidak mendapatkan kritikan di tempat kerja.

Kemudian pada informan AS hasil wawancara berdasarkan aspek resiliensi emotion regulation adalah :

"Alhamdulilah selama saya bekerja di Bri Syariah saya tidak pernah mendapatkan kritikan dan perlakuan yang istimewa artinya karena saya 
difabel saya di khusus kan perilakunya tidak seperti itu jadi saya tetep profesional bekerja".

Informan tidak pernah mendapatkan kritikan selama bekerja, baik bekerja di Bank BRI ataupun di LP2ES.

Kemudian pada informan KA hasil wawancara berdasarkan aspek resiliensi emotion regulation adalah :

"ya gini mba kan kita lagi ngumpul di rumah temen aku, ada makanan aku ambil pake tangan kiri temenku bilang kalo makan yang sopan ya pake tangan kanan".

Informan tidak pernah mendapatkan kritikan ditempat kerja, melainkan mendapatkan kritikan di lingkungan rumah.

Hasil wawancara berdasarkan aspek resiliensi yaitu impuls control dengan informan ER adalah :

"Tidak ada sudah cukup. Karena saya pernah menjadi prodi, saya pernah jadi dosen kemahasiswaan".

Informan tidak memiliki keinginan ditempat kerja karena informan sudah pernah menjabat jadi ketua program studi.

Kemudian pada informan AS hasil wawancara berdasarkan aspek resiliensi impuls control adalah :

"Kalo di tempat kerja instansi saya pengen nya siswa nya jadi bertambah tahun ini. Saya di libatkan untuk promosi dan menambah siswa jadi saya pengen nya ikut berkontribusi dengan bertambah nya siswa".

Informan memiliki keinginan yaitu ingin tetap menjadi dosen dan ingin menjadi ketua di PPDI.

Kemudian pada informan KA hasil wawancara berdasarkan aspek resiliensi impuls control adalah :

"Kalo di pekerjaan si ya pengen nya meningkat dalam arti profesinya jadi karyawan tetap apa gimana gitu"

Informan menginginkan menjadi karyawan tetap di tempat kerja karena informan masih menjadi karyawan kontrak. 
Hasil wawancara berdasarkan aspek resiliensi yaitu Optimism dengan informan ER adalah :

"Ya saya sekarang lagi belajar treder forex saya lagi menekuni itu sekarang".

Informan menekuni treder forex yaitu saham melalui HandPhone untuk masa depan informan.

Kemudian pada informan AS hasil wawancara berdasarkan aspek resiliensi Optimism adalah :

"Kalo untuk masa depan saya pengen nya berjalan dua dua nya. Artinya saya tetep bekerja di pendidikan dan saya tetep melanjutkan organisasi".

Informan memiliki rencana masa depan dengan tetap menjadi ketua organisasi dan menjadi dosen.

Kemudian pada informan KA hasil wawancara berdasarkan aspek resiliensi Optimism adalah :

"Ya apa ya mba kalo simpel nya si mencari Ridho Allah kalo dari duniawi kan mencari kebahagiaan dalam arti mencari pasangan yang terima aku apa adanya udh itu aja si mba".

Informan memiliki rencana masa depan dengan mencari ridho Allah dan mencari pasangan hidup yang menerima apa adanya keadaan informan.

Hasil wawancara berdasarkan aspek resiliensi yaitu Casual Analysis dengan informan ER adalah :

"Engga sama sekali, Naik motor, lya saya bawa"

Informan tidak memiliki kesulitan dalam bekerja, informan menggunakan tongkat saat bekerja dan tidak mengalami kesulitan dalam menggunakan tongkat.

Kemudian pada informan AS hasil wawancara berdasarkan aspek resiliensi Casual Analysis adalah :

"Dalam pekerjaan kesulitan itu akan selalu ada kita tidak bisa predikisi kesulitan tersebut. Misalnya waktu saya bekerja di bank, pencairan dana tidak selama nya pencairan akan berjalan lancar pasti akan timbul konflik. itu salah satu kesulitan yang saya alami dalam bekerja". 
Informan merasakan kesulitan pada saat bekerja di Bank mengenai pencairan dana.

Kemudian pada informan KA hasil wawancara berdasarkan aspek resiliensi Casual Analysis adalah :

"Hmmm ada mba mungkin cuma di tingkat kecepatan aja mba karna kan aku difabel tangan dan aku di call center jadi selain mendengarkan customer aku sambilan ngetik juga mba".

Informan mengalami kesulitan ditempat kerja pada saat mengetik menggunakan satu tangan.

Hasil wawancara berdasarkan aspek resiliensi yaitu Emphaty dengan informan ER adalah :

"Alhamdulillah baik karena kan dalam bekerja kita harus berkomunikasi kalo engga kita bakalan kesusahan sendiri. Kita juga pasti butuh bantuan orang lain maka dari itu kita perlu komunikasi yang baik dengan orang lain".

Informan memiliki komunikasi yang baik dengan rekan kerja dan menurut informan membangun komunikasi sangat penting dan diperlukan.

Kemudian pada informan AS hasil wawancara berdasarkan aspek resiliensi Emphaty adalah :

"Alhamdulilah baik, kita tetep menjalin komunikasi dengan kita setiap minggu metting bahas siswa, bahas sudah berapa yang masuk ke sekolah ini dan yang lain".

Informan memiliki komunikasi yang baik dengan rekan kerja, karena setiap minggu informan dan rekan kerja melaksanakan meeting untuk menjalin komunikasi dan kemajuan kampus tempat informan bekerja.

Kemudian pada informan KA hasil wawancara berdasarkan aspek resiliensi Emphaty adalah :

"Awalnya ga baik mba, ya karena senioritas mba kan pas awal akudi ajarin kaya training gitu mba. Jadi senior itu ngomongnya kaya pake nada tingi, kadang jutek cuek. Ya sekarang udah baik si 
mba karena udah tau sifatnya juga dan mungkin karena udah terbiasa juga mba".

Komunikasi informan dengan rekan kerja pada saat awal bekerja tidak baik dikarenakan senioritas. Informan mencoba memahami sifat dari rekan kerja. Beberapa bulan kemudian komunikasi informan dengan rekan kerja baik karena sudah memahaminya.

Hasil wawancara berdasarkan aspek resiliensi yaitu Self-Eficacy dengan informan ER adalah :

"Pasti pernah. Tapi sebisa mungkin saya atasi sendiri. Contoh masalah keluarga karena saya kepala keluarga saya mencoba untuk menyelesaikan nya sendiri. Kalo sekiranya saya ga bisa saya komunikasi kan dengan istri".

Informan mengkomunikasikan kepada isteri apabila tidak bisa menyelesaikan permasalahan yang di hadapinya.

Kemudian pada informan AS hasil wawancara berdasarkan aspek resiliensi Self-Eficacy adalah :

"Alhamdulillah selama saya menjadi difabel seperti ini, hambatan-hambatan seperti itu tidak saya pikirkan karena sama seperti tadi otak saya tidak akan berkembang".

Informan mampu menyelesaikan masalah yang dihadapi, dan tidak menganggap hambatan menjadi batas dalam menjalankan sesuatu.

Kemudian pada informan KA hasil wawancara berdasarkan aspek resiliensi Self-Eficacy adalah :

"Kita berusaha semampu kita dulu untuk selesein masalah sendiri.Kalo semisal kita merasa ga mampu ya mau gamau kita minta bantuan senior".

Informan mencari solusi dengan meminta bantuan kepada senior yang sudah berpengalaman untuk menyelesaikan permasalahan yang sedang dihadapinya.

Hasil wawancara berdasarkan aspek resiliensi yaitu Reaching out dengan informan ER adalah : 
"Saya tetep bekerja mau gimana pun kondisi saya. Karena saya punya tanggung jawab disana jadi saya tetep bekerja".

Informan akan terus bekerja walau keadaan fisik informan tidak seperti orang pada umumnya.

Kemudian pada informan AS hasil wawancara berdasarkan aspek resiliensi Reaching Outadalah:

"Pernah saya ke SMK mau sosialisi. Kan saya kebagian masuk kelas yang ada di atas sedangkan saya berjalan harus mengangkat sedikit kaki saya. Itu hambatan nya si"

Informan memiliki hambatan pada saat mensosialisasikan kampus ke sekolah sekolah yang berada di desa. Informan mengalami hambatan pada saat akan menaiki anak tangga sekolah.

Kemudian pada informan KA hasil wawancara berdasarkan aspek resiliensi Reaching Out adalah :

"Hambatan di pekerjaan ada mba. Tentang nasabah mba jadi setiap ada nasabah yang komplain kita tetep bikin laporan. Nah setelah bikin laporan nya itu kita bingung tujuan setelah laporan nya kemana mba".

Informan mengalami hambatan ditempat kerja mengenai laporan tentang nasabah.

\section{Diskusi}

Hasil penelitian ini menyebutkan bahwa 3 informan masuk kedalam resiliensi dengan kategori baik, karena hasil wawancara dengan aspek resiliensi sesuai. Penjelasan di atas sejalan dengan yang diungkapkan oleh Hildayani (dalam Dipayanti, 2012) resliensi adalah kemampuan yang dimiliki individu dan dengan kemampuan tersebut individu mampu bertahan dan berkembang secara sehat serta menjalani kehidupan secara positif dalam situasi yang kurang menguntungkan dan penuh dengan tekanan. Individu yang resilien akan mampu bertahan dibawah tekanan atau kesedihan dan tidak menunjukan suasana hati yang negatif terus menerus. 
Pada kehidupan individu yang mengalami tunadaksa non bawaan yang bekerja banyak menemui situasi yang menekan. Ketiga informan menghadapi kesulitan dengan mendapatkan kritikan mengenai kondisi fisik. Kritikan tersebut masih bisa di kendalikan oleh ketiga informan dengan cara menanggapi kritikan tersebut dengan perlakuan yang positif seperti diam dan tersenyum.

Sejalan dengan pendapat dari (Gross \& Thompson, 2007) mengevaluasi emosi yaitu individu untuk mengelola dan menyeimbangkan emosi-emosi yang di alami. Kemampuan mengelola emosi-emosi khususnya emosi negatif seperti kemarahan, kesedihan, kecewa, dendam dan benci akan membuat individu tidak terbawa dan terpengaruh secara mendalam (Rahmawati, 2015).

Kemampuan untuk tetap positif tentang masa depan namun realistis dalam perencanaan. Ini terkait dengan harga diri tetapi ada hubungan yang lebih kausal dengan efikasi diri dan melibatkan akurasi dan realisme. Sesuai dengan penelitian dari (Sari, 2017) yang menyatakan bahwa seseorang yang memiliki resiliensi baik adalah orang yang optimis, karena ada keyakinan bahwa segala sesuatu dapat berubah menjadi baik.

Kemampuan untuk mengidentifikasi penyebab kesulitan secara akurat. Orang yang tangguh mampu keluar dari gaya berpikir kebiasaannya untuk mengidentifikasi lebih banyak kemungkinan penyebab dan dengan demikian lebih banyak solusi potensial. Hal ini sesuai dengan pendapat Syaiful (dalam Kusmanto, 2014) berpikir merupakan suatu kegiatan mental yang dialami seseorang bila individu dihadapkan pada suatu masalah atau situasi yang harus dipecahkan.

Kemampuan untuk membaca isyarat perilaku orang lain untuk memahami keadaan psikologis dan emosional subjek dan dengan demikian membangun hubungan yang lebih baik. Orang yang tangguh dapat membaca isyarat non-verbal orang lain untuk membantu membangun hubungan yang lebih dalam dengan orang lain, dan cenderung lebih selaras dengan keadaan emosi sendiri. Komunikasi empati komunikasi yang dilandasi kesadaran untuk memahami dengan perasaan, kepedulian dan perhatian terhadap komunikan. Maka dari itu dalam komunikasi empati yang perlu diperhatikan adalah cara memahami orang lain (Masturi, 2010). 
Pengertian bahwa individu efektif di dunia, keyakinan bahwa individu dapat menyelesaikan masalah dan berhasil. Orang-orang yang tangguh percaya pada dirinya sendiri dan sebagai hasilnya membangun kepercayaan orang lain, menempatkan di garis untuk lebih sukses dan lebih banyak kesempatan. Sejalan dengan pendapat Schunk (dalam Purnamasari, 2013) efikasi diri merupakan keyakinan tentang apa yang mampu dilakukan oleh seseorang. Efikasi diri dapat diatur oleh seseorang dengan menilai keterampilan-keterampilan dan kapabilitas untuk menerjemahkan keterampilan tersebut kedalam tindakan.

Kemampuan untuk meningkatkan aspek positif kehidupan dan menghadapi tantangan dan peluang baru. Menjangkau perilaku dihambat oleh rasa malu, perfeksionisme, dan cacat diri. Sejalan dengan penelitian yang dilakukan sebelumnya, individu yang percaya bahwa ada harapan pada masa depan bagi dirinya sendiri sehingga dapat mengontrol arah kehidupannya, yakin pada kemampuannya dalam mengatasi masalah hal tersebut menujukan sikap optimis. Memiliki optimisme dalan diri sendiri akan membentuk kemampuan untuk meraih apa yang di inginkan atau disebut dengan pencapaian (reaching out) (Hidayati, 2014).

\section{Kesimpulan}

Berdasarkan hasil temuan dan diskusi yang telah dijelaskan maka dapat disimpulkan bahwa resiliensi pria tunadaksa nonbawaan yang bekerja memiliki resiliensi yang dapat dikategorikan dalam kategori baik. Aspek resiliensi yang mempengaruhi dapat di temukan dalam penelitian ini di antaranya berbagai situasi atau kondisi yang menekan dan permasalahan yang dihadapi seperti menerima kritikan mengenai kondisi fisik. Menanggapi kritikan yang diterimanya sebagai pria tunadaksa dengan diam dan tersenyum tidak ada tidakan atau respon terhadap kritikan tersebut, secara tidak langsung mengasah kemampuan untuk dapat mengontrol emosi dalam berbagai keadaan (emotion regulation). Dapat mengendalikan keinginan, dorongan serta tekanan yang muncul dari dalam diri (impuls control). Seperti mengurangi pengeluaran untuk membeli keperluan pribadi, 
agar dapat menabung dan dapat membangun sebuah rumah. Pria tunadaksa juga dapat memiliki rencana masa depan dan berusaha mewujudkannya (optimism), seperti memiliki rencana masa depan yaitu ingin investasi saham melalui Handphone dan menekuninya dengan baik.

Menyadari penyebab permasalahan yang dihadapi (causal analysis) seperti merasakan kesulitan pada tingkat kecepatan dalam mengetik dan berusaha mengatasi sendiri kesulitan tersebut. Memiliki hubungan yang baik dengan rekan kerja maupun lingkungan sekitar rumah, mengerti permasalahan yang dihadapi orang lain (emphaty). Seperti memahami sifat dari individu untuk dapat berkomunikasi dengan baik.

Mampu melakukan berbagai usaha untuk dapat memecahkan sebuah permasalahan (self-eficacy). Seperti meminta bantuan orang lain yang lebih berpengalaman dalam menyelesaikan masalah. Memiliki kemampuan untuk meningkatkan aspek positif kehidupan dan menghadapi tantangan baru (reaching out). Seperti tidak menggap suatu hambatan sebagai penghalang untuk tetap melakukan sesuatu.

\section{Daftar Pustaka}

Abiyoga, M. I., \& Sawitri, D. R. (2018). "Tabah didalam Kekuranganku” Studi Kualitatif Mengenai Hardiness pada Individu Dewasa Madya Penyandang Tunadaksa yang Bekerja. Empati, 6(4), 25-32.

Afriany, J. (2018). Penilaiandan Etos Kerjaterhadap Motivasi TunadaksadiSumatera Utara. Majalah IImiah INTI (Informasi dan Teknologi IImiah), 13(1), 12-15.

Anggraeni, R. R. (2008). Resiliensi pada Penyandang Tuna Daksa Pasca Kecelakaan. Jurnal Psikologi.

Alsa, A. (2003). Pendekatan Kuantitatif dan Kualitatif serta Kombinasinya dalam Penelitian Psikologi. Yogyakarta: Pustaka Pelajar.

Aprilia, W. (2013). Resiliensi dan Dukungan Sosial pada Orang Tua Tunggal(Studi Kasus pada Ibu Tunggal di Samarinda). E-JournalPsikologi, 1(3), 268-279. 
Bungin, B. (2007). Analisis Data Penelitian Kualitatif. PT RajaGrafindo Persada.

Cresswel, J. W. (1994). Research design: Qualitative and quantitative approaches. Amerika: SAGE Publications.

Damayanti, S. Rostiana. 2003. Dinamika Emosi Penyandang Tunadaksa Pasca Kecelakaan. Jurnal Ilmiah Psikologi Arkhe, 8(1), 15-28.

Dipayanti, S., \& Chairani, L. (2012). Locus of Control dan Resiliensi pada Remaja yang Orang Tuanya Bercerai. Jurnal Psikologi, 8(1), 15-20.

Gross, J. J., \& Thompson, R. A. (2007). Emotion regulation: Conceptual foundations.

Hardjajani, T., \& Nugroho, A. A. (2013). Hubungan antara Dukungan Sosial dan Efikasi Diri dengan Kecemasan Menghadapi Dunia Kerja pada Penyandang Tuna Daksa. Jurnal Ilmiah Psikologi Candrajiwa, 2(1).

Hidayati, N. L. (2014). Hubungan antara Self-Esteem dengan Resiliensi pada Remaja di Panti Asuhan Keluarga Yatim Muhammadiyah Surakarta (Doctoral Dissertation, Universitas Muhammadiyah Surakarta).

Hikmawati, E., \& Rusmiyati, C. (2011). Kebutuhan pelayanan sosial penyandang cacat. Sosio Informa, 16(1).

Herman, J. (2015). Resiliensi pada Penyandang Tuna Daksa (Doctoral dissertation, Universitas Gadjah Mada).

Jackson, R., \& Watkin, C. (2004). The resilience inventory: seven essential skills for overcoming life's obstacles and determining happiness. Selection \&Development Review, 20(6), 13-17.

Kusmanto, H. (2014). Pengaruh Berpikir Kristis Terhadap Kemampuan Siswa Dalam Memecahkan Masalah Matematika (Studi Kasus Di Kelas VII SMP Wahid Hasyim Moga). Eduma: Mathematics Education Learning and Teaching, 3(1).

Listiana, A. R. (2016). Perkembangan Psikoseksualpada Anak dengan Berkebutuhan Khusus Tunadaksa Cerebral Palsy(Disertasi, Universitas Muhammadiyah Purwokerto).

Machdan, D. M., \& Hartini, N. (2012). Hubungan antara Penerimaan Diri dengan Kecemasan Menghadapi Dunia Kerja pada Tunadaksa di UptRehabilitasi Sosial Cacat Tubuh Pasuruan. Jurnal Psikologi Klinis dan Kesehatan Mental, 1(02). 
Masturi, A. (2010). Membangun Relasi Sosial Melalui Komunikasi Empatik (Perspektif Psikologi Komunikasi). KOMUNIKA: Jurnal Dakwah dan Komunikasi, 4(1), 14-31.

Merdiasi, D. (2017). Gambaran Tuna Daksa yang Bekerja. Jurnal Psychology, 3(2), 60-81.

Mufidah, A. C. (2017). Hubungan Antara Dukungan Sosial Terhadap Resiliensi Mahasiswa Bidikmisi Dengan Mediasi Efikasi Diri. Jurnal Sains Psikologi, 6(2), 68-74.

Moleong, L.J. (2013). Metodologi Penelitian Kualitatif. Bandung: PT.Remaja Rosdakarya.

Nurtjahjanti, H., \& Ratnaningsih, I. Z. (2011). Hubungan Kepribadian Hardiness dengan Optimisme pada Calon Tenaga Kerja Indonesia (CTKI) Wanita di BLKLN Disnakertrans Jawa Tengah. Jurnal Psikologi Undip, 10(2), 126-132.

Noor, N. M \& Alwi, A. (2013). Stressor and Well Being in Low Socioeconomic Status Malaysian Adolescents: The Role Of Resilience Resources. AsianJournal of Social Psychology, 16 (4), 292-306.

Novianti, R. (2018). Orang Tua sebagai Pemeran Utama dalam Menumbuhkan Resiliensi Anak. Jurnal Educhild: Pendidikan dan Sosial, 7(1), 26-33.

Purnamasari, D. (2013). Faktor-faktor yang Mempengaruhi Kecurangan Akademik pada Mahasiswa. Educational Psychology Journal, 2(1). 